\title{
SDS-PAGE AND NUMERICAL ANALYSIS OF CANDIDA ALBICANS FROM HUMAN ORAL CAVITY AND OTHER ANATOMICAL SITES
}

\author{
Cristina Crespo Rodrigues ${ }^{1}$; José Francisco Höfling ${ }^{1 *}$; Marcelo Fabiano Gomes Boriollo ${ }^{1}$; \\ Janaina Aparecida de Oliveira Rodrigues ${ }^{1}$; Ricardo Antunes de Azevedo²; Reginaldo Bruno Gonçalves ${ }^{1}$; \\ Luiz Humberto Gomes ${ }^{3}$; Flávio César Almeida Tavares ${ }^{3}$
}

${ }^{1}$ Departamento de Diagnóstico Oral, Laboratório de Microbiologia e Imunologia, Faculdade de Odontologia de Piracicaba da Universidade Estadual de Campinas, Piracicaba, SP, Brasil; ${ }^{2}$ Departamento de Genética, Laboratório de Genética e Bioquímica de Plantas, Escola Superior de Agricultura "Luiz de Queiroz" da Universidade Estadual de São Paulo, Piracicaba, SP, Brasil;

${ }^{3}$ Departamento de Genética, Laboratório de Genética de Leveduras, Escola Superior de Agricultura "Luiz de Queiroz" da Universidade Estadual de São Paulo, Piracicaba, SP, Brasil.

Submitted: November 13, 2002; Returned to authors: May 19, 2003; Approved: February 10, 2004.

\begin{abstract}
The aim of the present research was to evaluate the protein polymorphism degrees among forty-eight $C$. albicans isolates from fourteen anatomical sites of clinical patients by polyacrylamide gel electrophoresis (SDS-PAGE) and numerical analyzes, in order to identify subspecies and their similarities in some infectious niches. Cell cultures were grown in YEPD medium, collected by centrifugation, and washed in cold saline solution. The whole-cell proteins were extracted by cell disruption using glass beads and submitted to SDSPAGE technique. After electrophoresis, the protein bands were stained with coomassie-blue and analyzed by statistics package NTSYS-pc version 1.70 software. Similarity matrixes and dendrograms were generated by application of similarity coefficient of simple matching and UPGMA algorithm, respectively. The results obtained showed several C. albicans subtypes and their similarity degrees (80\% to $100 \%)$. Such data showed that same patients may be infected by two or more $C$. albicans subtypes in certain anatomical sites (i.e. only in oral cavity of immunocompromised patients, blood, or tracheal secretion), or yet, two or more patients can be infected in identical anatomical sites (i.e. bronchial washing, urine, oral cavity, tracheal secretion, vaginal secretion, and healthy saliva) with a same $C$. albicans subtype. However, two or more patients also can show infections in corresponding sites (i.e. oral cavity of immunocompromised patients, blood, oropharyngeal secretion, oral cavity, tracheal secretion, vaginal secretion, and healthy saliva) by different $C$. albicans subtypes. Besides, two or more patients also can be infected with identical or different $C$. albicans subtypes in different anatomical sites (i.e.1. identical subtypes in vaginal secretion, tracheal secretion, and urine; abdominal secretion and spittle; drainage and oral cavity; catheter and healthy saliva - i.e.2. subtypes different in bronchial washing, oropharyngeal secretion, pulmonary secretion, oral cavity of immunocompromised patients, and blood). Complementary studies involving C. albicans sample isolated from several anatomical sites of immunocompetent or immunocompromised patients (before, during and after specifics therapies) and their families or hospital workers must be done in order to establish the sources of $C$. albicans colonization. The whole-cell proteins profile performed by SDS-PAGE associated with computerassisted numerical analysis may provide preliminary criteria for taxonomic and epidemiological studies of such microorganisms.
\end{abstract}

Key words: numerical analyzes, SDS-PAGE, $C$. albicans, human anatomical sites

*Corresponding author. Mailing address: Av. Limeira, 901, Areião, C.P. 052. 13414-903, Piracicaba, SP, Brasil. Tel.: (+5519) 34125321. E-mail: hofling@fop.unicamp.br 


\section{INTRODUCTION}

Human beings carry the yeast Candida albicans and other Candida species as part of their commensal microbiota. However, in hosts predisposed to candidiasis, such as AIDS, diabetes, organ transplant, tumors and others, these yeasts may act as pathogens $(24,36)$. Commensal Candida species inhabiting the oral cavity, vaginal canal, and gastrointestinal tract of host may begin the infectious process $(15,20,29,32)$. Different types of electrophoretic techniques have been used for the characterization or typing of Candida species including separation of chromosomes, DNA fragments, isoenzymes, cell-wall glycoproteins and whole-cell proteins $(5,8,9,28,30,34,45,47,50)$. In regard to whole-cell proteins, their separation has been employed satisfactorily in the characterization of bacteria and yeast $(13,22,26,55,56,57,58)$. Many investigators employed electrophoretic analysis of whole-cell proteins in the fungi taxonomy $(19,21,49,58)$. The polyacrylamide gel electrophoresis also has been used in the identification of oral yeasts. This technique showed high specificity in addition to the significant data for classification (30). In several cases, unidimensional electropherograms of whole-cell proteins and DNA-DNA hybridization data were equalized as their discriminatory capacities $(10,23,25,26,37)$. Besides, the comparison of electrophoretic proteins patterns has been considered a technique with satisfactory taxonomic resolution, which can be applicable to the level of species, subspecies and biotypes (25). Based on the findings of the available literature, the aim of the present investigation was to analyze the similarity degrees of protein profiles among $C$. albicans isolates from some anatomical sites of clinical patients by polyacrylamide gel electrophoresis (SDS-PAGE) and numerical analyzes, in order to identify subspecies and their similarities in the infectious niches.

\section{MATERIALS AND METHODS}

\section{Yeast isolation, cell cultivation and whole-cell protein extraction}

A total of forty-eight C. albicans isolates from fourteen anatomical sites of forty-two clinical patients (immunocompetent and immunocompromised) were analyzed (Table 1). All strains were grown in $50 \mathrm{~mL}$ of YEPD medium (2\% dextrose, $2 \%$ peptone, $1 \%$ yeast extract) in a shaker table under $150 \mathrm{rpm}$, at $30^{\circ} \mathrm{C}$, overnight (late log phase-approx $10^{8} \mathrm{cells} / \mathrm{mL}$ ) (5,9). After growth, cells were harvested by centrifugation at 3,000g for 5 min and the pellets were washed three times in cold
Table 1. Samples of C. albicans collected from several anatomical sites.

\begin{tabular}{|c|c|c|c|}
\hline Origin & Anatomical site & $\begin{array}{c}\text { Sample } \\
\text { Code }\end{array}$ & Patients \\
\hline $\begin{array}{l}\text { Prevlab laboratory } \\
\text { of Piracicaba } \\
\text { Clinical Laboratory of } \\
\text { São Paulo State UNESP } \\
\text { (Botucatu campus) }\end{array}$ & $\begin{array}{l}\text { Urine } \\
\text { Oropharyngeal secretion } \\
\text { Spittle } \\
\text { Pulmonary secretion } \\
\text { Catheter }\end{array}$ & $\begin{array}{l}\text { P1 } \\
\text { IB2 } \\
\text { IB3 } \\
\text { IB4 } \\
\text { IB5 }\end{array}$ & $\begin{array}{l}1 \\
2 \\
3 \\
4 \\
5\end{array}$ \\
\hline $\begin{array}{l}\text { Adolfo Lutz Institute } \\
\text { of São Paulo State }\end{array}$ & $\begin{array}{l}\text { Oral cavity (HIV) } \\
\text { Oral cavity (HIV) } \\
\text { Oral cavity (HIV) } \\
\text { Oral cavity (HIV) } \\
\text { Oral cavity (HIV) } \\
\text { Urine } \\
\text { Urine } \\
\text { Urine } \\
\text { Urine } \\
\text { Bronchial washing } \\
\text { Bronchial washing } \\
\text { Blood } \\
\text { Blood } \\
\text { Abdominal secretion } \\
\text { Drainage } \\
\text { Oropharyngeal secretion } \\
\text { Tracheal secretion } \\
\text { Tracheal secretion } \\
\text { Tracheal secretion } \\
\text { Tracheal secretion } \\
\text { Vaginal secretion } \\
\text { Vaginal secretion } \\
\text { Vaginal secretion } \\
\text { Vaginal secretion } \\
\text { Vaginal secretion } \\
\text { Vaginal secretion } \\
\text { Vaginal secretion } \\
\text { Vaginal secretion }\end{array}$ & $\begin{array}{c}\text { AL1.2 } \\
\text { AL2.1 } \\
\text { AL2.2 } \\
\text { AL3.1 } \\
\text { AL3.2 } \\
\text { AL4 } \\
\text { AL5 } \\
\text { AL6 } \\
\text { AL7 } \\
\text { AL8.1 } \\
\text { AL8.2 } \\
\text { AL9.1 } \\
\text { AL9.2 } \\
\text { AL10 } \\
\text { AL11 } \\
\text { AL12 } \\
\text { AL13.1 } \\
\text { AL13.2 } \\
\text { AL13.3 } \\
\text { AL14 } \\
\text { AL15 } \\
\text { AL16 } \\
\text { AL17 } \\
\text { AL18 } \\
\text { AL20 } \\
\text { AL22 } \\
\text { AL23 } \\
\text { AL24 }\end{array}$ & $\begin{array}{l}6 \\
7 \\
7 \\
8 \\
8 \\
9 \\
10 \\
11 \\
12 \\
13 \\
13 \\
14 \\
14 \\
15 \\
16 \\
17 \\
18 \\
18 \\
18 \\
19 \\
20 \\
21 \\
22 \\
23 \\
24 \\
25 \\
26 \\
27\end{array}$ \\
\hline $\begin{array}{l}\text { Clinical Laboratory of } \\
\text { São Paulo State } \\
\text { University } \\
\text { (Botucatu campus) }\end{array}$ & $\begin{array}{l}\text { Urine } \\
\text { Urine } \\
\text { Blood } \\
\text { Tracheal secretion }\end{array}$ & $\begin{array}{l}\text { LC1 } \\
\text { LC2 } \\
\text { LC3 } \\
\text { LC4 }\end{array}$ & $\begin{array}{l}28 \\
29 \\
30 \\
31\end{array}$ \\
\hline $\begin{array}{l}\text { São José dos Campos } \\
\text { State University/UNESP }\end{array}$ & $\begin{array}{l}\text { Oral cavity } \\
\text { Oral cavity } \\
\text { Oral cavity }\end{array}$ & $\begin{array}{l}\text { F72 } \\
97 \mathrm{~A} \\
\mathrm{E} 37\end{array}$ & $\begin{array}{l}32 \\
33 \\
34\end{array}$ \\
\hline $\begin{array}{l}\text { School of Dentistry / } \\
\text { UNICAMP (Piracicaba } \\
\text { campus) }\end{array}$ & $\begin{array}{l}\text { Saliva (healthy) } \\
\text { Saliva (healthy) } \\
\text { Saliva (healthy) } \\
\text { Saliva (healthy) } \\
\text { Saliva (healthy) } \\
\text { Saliva (healthy) } \\
\text { Saliva (healthy) } \\
\text { Saliva (healthy) }\end{array}$ & $\begin{array}{c}\text { A19 } \\
\text { A116 } \\
\text { B44 } \\
\text { C46 } \\
\text { C75 } \\
\text { D47 } \\
\text { D68 } \\
\text { E5 }\end{array}$ & $\begin{array}{l}35 \\
36 \\
37 \\
38 \\
39 \\
40 \\
41 \\
42\end{array}$ \\
\hline
\end{tabular}


sterile $0.9 \% \mathrm{NaCl}$ in order to remove either culture medium traces or extra-cellular metabolites $(59,60)$. The last washed pellets were transferred to micro-centrifuge tubes $(2 \mathrm{~mL})$ and glass beads $(\mathrm{v} / \mathrm{v})$ plus $500 \mathrm{~mL}$ of cold sterile water were added $(3,41)$. Cells were lysed using a Mini-Bead Beater cell disrupter (Biospec Products, Inc.) at 4,200 rpm, repeating four times of $30 \mathrm{sec}$ at $5 \mathrm{~min}$ intervals, and placed in an ice bath $(3,41)$. After cell disruption, were centrifuged at $10,000 \mathrm{~g}$ for $5 \mathrm{~min}$, and the supernatant protein concentration were determined according to Bradford $(6,16)$ and adjusted to $0.8 \mathrm{mg} . \mathrm{mL}^{-1}(2)$. Equal volumes of supernatant and loading buffer (5 mM Tris, 2.5\% 2-mercaptoethanol, 1.5\% SDS, $0.025 \%$ bromophenol blue, $15 \%$ glycerol) were combined and heated in a boiling water bath for $10 \mathrm{~min}(8)$.

\section{Polyacrylamide gel electrophoresis (PAGE)}

SDS-PAGE protein profiles were obtained after electrophoresis of $25 \mathrm{~mL}$ of denatured protein solution in polyacrylamide slab gel (55) with SDS (sodioum dodecylsufate) in a discontinuous buffer system (27) with $4.5 \%$ stacking gel and $12.5 \%$ running gel. The electrophoresis was performed at 125 volts in a cold chamber and the protein bands present in gels were fixed in solution of $12.5 \%$ sulfosalicylic acid for 20 min and stained with $0.025 \%$ Coomassie Blue G-250 for $12 \mathrm{~h}$. The gels were destained by successive washing in acetic acid:methanol:water (1:2.5:6.5) solution (1).

\section{Numerical Analysis}

The images of the gels were captured using an HP 4C scanner (Hewlett Packard Co.) and the relative mobility (Rm values and/ or molecular weights) of each protein band was determined by Kodak Digital Science software ${ }^{\mathrm{TM}}$. Matches and mismatches among the bands (originated from presence/absence of protein bands) received the representations 1 and 0 , respectively. These data allowed to build binary values matrixes that were analyzed using the statistics package NTSYS-pc version 1.70 (Applied Biostatistics, Inc.). The similarity coefficient of Simple Matching, $S_{S M}=(\mathrm{a}+\mathrm{d}) \cdot(\mathrm{a}+\mathrm{b}+\mathrm{c}+\mathrm{d})^{-1}$, was used to obtain the matrixes of similarity $\left(S_{S M}\right)$. Dendrograms, represented by non-rooted trees, based on $S_{S M}$ values were generated by the unweighted pairgroup arithmetic average (UPGMA) clustering method (17,51,52). The type-strain of $C$. albicans CBS562 and molecular weight markers (Bovine Serum Albumin 66,000Da, Bovine Pancreas Trypsinogen 24,000Da, Bovine Milk b-Lactoglobulin $18,400 \mathrm{Da}$-Sigma-Aldrich Co.) were included in this experiment in order to establish the degree of similarity among the $C$. albicans samples and to determinate reproducibility $(8,13,14,58)$.

\section{RESULTS}

\section{Reproducibility}

The strains protein profiles on different gels were reproducible after three repetitions of each electrophoretic running. Protein extracts of C. albicans CBS562 and molecular weight markers were applied in all gels providing mean value $S_{S M}=0.921$.

\section{Strain clustering}

The electrophoretic whole-cell protein patterns of $C$. albicans showed 20 major bands per lane, within a range molecular weight varying between $18,400 \mathrm{Da}$ and $66,000 \mathrm{Da}$ (Fig. 1). The application of UPGMA clustering method allowed to build ten similarity dendrograms (Fig. 2) with $0.8^{80 \%} \leq S_{S M} \leq 1.0^{100 \%}$. Such dendrograms showed one or several C. albicans subtypes, which were determined according to the electrophoretic whole-cell protein patterns and their similarity degrees:

Dendrogram I (Oral cavity - HIV): presence of 5 C. albicans subtypes isolated from patients 6 (AL1.2), 7 (AL2.1, AL2.2), and 8 (AL3.1, AL3.2), with $0.8<S_{S M}<1.0$.

Dendrogram II (Bronchial washing): presence of only $1 C$. albicans subtype isolated from patient 13 (AL8.1, AL8.2), with $S_{S M}=1.0$.

Dendrogram III (Blood): presence of 3 C. albicans subtypes isolated from patients 14 (AL9.1, AL9.2) and 30 (LC3), with $0.8<S_{S M}<1.0$.

Dendrogram IV (Oropharyngeal secretion): presence of 2 C. albicans subtypes isolated from patients 2 (IB2) and 17 (AL12), with $0.8<S_{S M}<1.0$.

Dendrogram $\mathbf{V}$ (Urine): presence of only 1 C. albicans subtype isolated from patients 1 (P1), 9 (AL4), 10 (AL5), 11 (AL6), 12 (AL7), 28 (LC1), and 29 (LC2), with $S_{S M}=1.0$.

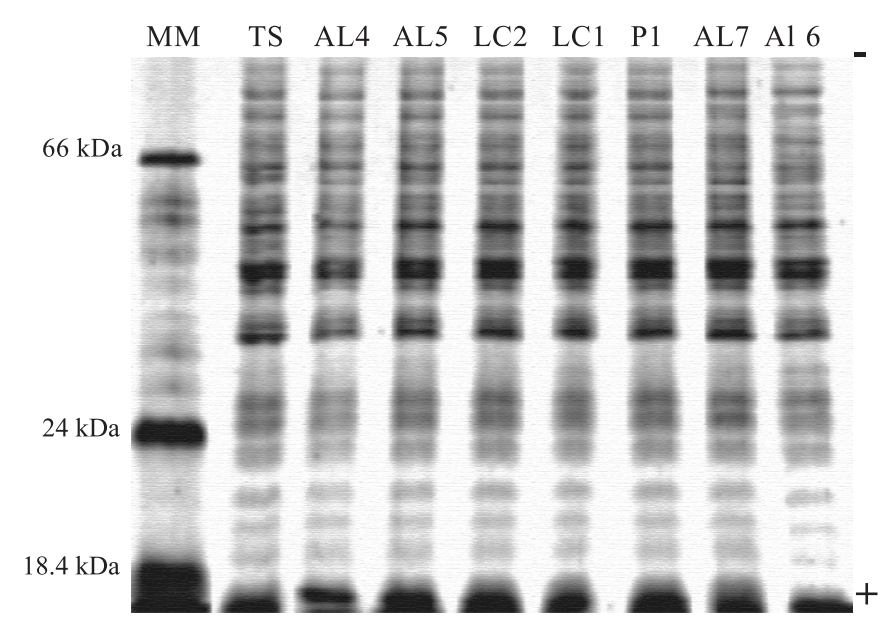

Figure 1. Electrophoregram of whole-cell protein profiles of $C$. albicans sample isolated from urine. MM: Molecular weight rkers (Bovine Serum Albumin 66,000Da, Bovine Pancreas Trypsinogen 24,000Da, Bovine Milk b-Lactoglobulin 18,400Da - Sigma-Aldrich Co.). TS: C. albicans CBS562 (type-strain). 
Figure 2. UPGMA dendrograms. Relationship among C. albicans subtypes isolated from several human anatomical sites, based on their protein profiles by SDS-PAGE.

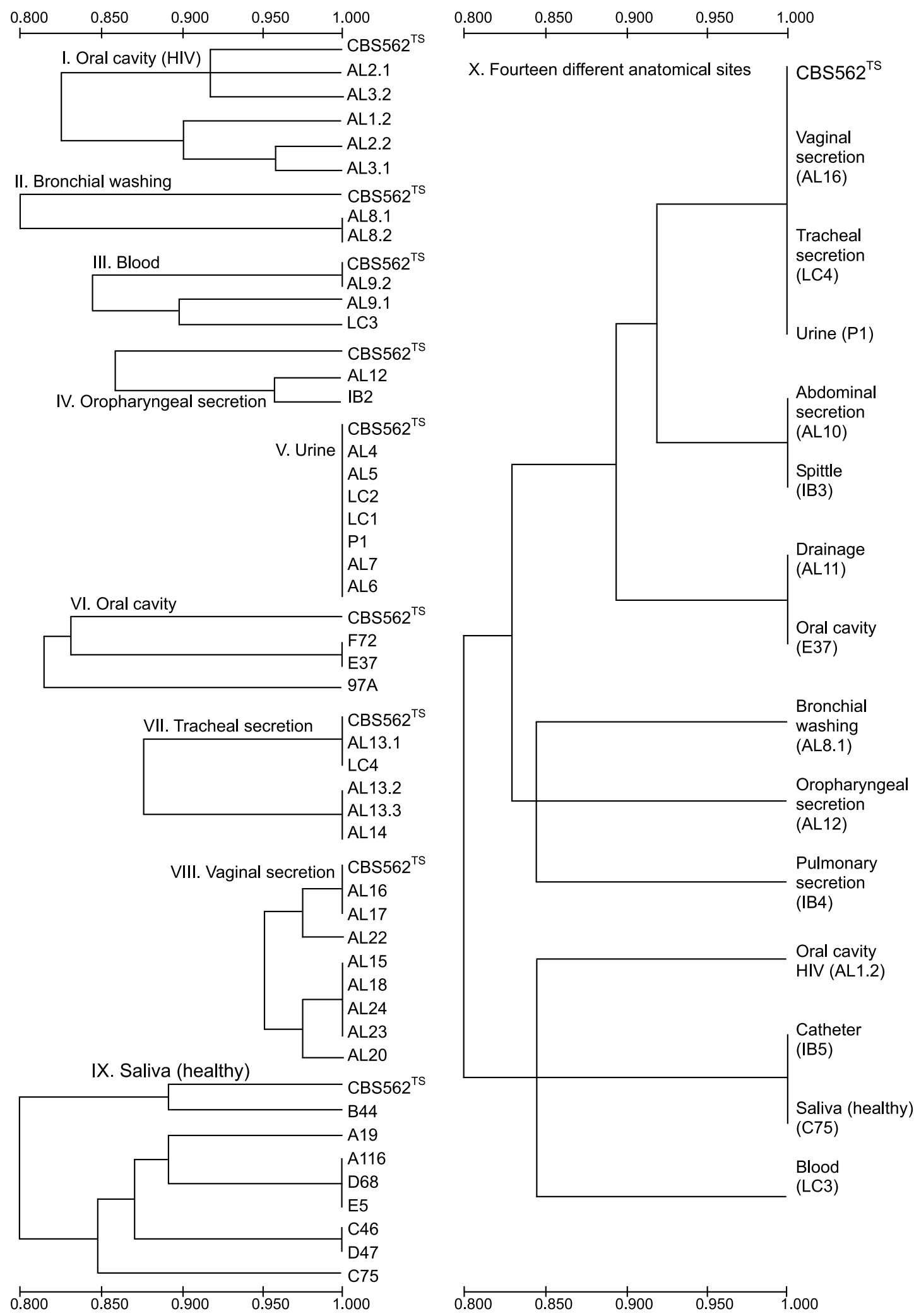


Dendrogram VI (Cavity oral): presence of 2 C. albicans subtypes isolated from patients 32 (F72), 33 (97A), and 34 (E37), with $0.8<S_{S M} \leq 1.0$.

Dendrogram VII (Tracheal secretion): presence of $2 C$. albicans subtypes isolated from patients 18 (AL13.1, AL13.2, AL13.3), 19 (AL14), and 31 (LC4), with $0.8<S_{S M} \leq 1.0$.

Dendrogram VIII (Vaginal secretion): presence of $4 C$. albicans subtypes isolated from patients 20 (AL15), 21 (AL16), 22 (AL17), 23 (AL18), 24 (AL20), 25 (AL22), 26 (AL23), and 27 (AL24), with $0.8<S_{S M} \leq 1.0$.

Dendrogram IX (Saliva - healthy): presence of 5 C. albicans subtypes isolated from patients 35 (A19), 36 (A116), 37 (B44), 38 (C46), 39 (C75), 40 (D47), 41 (D68), and 42 (E5), with $0.8<S_{S M} \leq 1.0$.

Dendrogram $X$ (one isolate representative of each anatomical site chosen casually): presence of 9 C. albicans subtypes isolated from 14 anatomical sites [vaginal secretion (AL16), tracheal secretion (LC4), urine (P1), abdominal secretion (AL10), spittle (IB3), drainage (AL11), oral cavity (E37), bronchial washing (AL8.1), oropharyngeal secretion (AL12), pulmonary secretion (IB4), oral cavity - HIV (AL1.2), catheter (IB5), saliva - healthy (C75), and blood (LC3)] of 14 patients, with $0.8<S_{S M} \leq 1.0$.

\section{DISCUSSION}

In the present investigation forty-eight $C$. albicans samples from several anatomical sites of different patients were analyzed by SDS-PAGE and numerical analysis. The reproducibility of the electrophoretic protein profiles on different slab gels, evaluated by the inclusion of molecular weight markers and protein extracts of $C$. albicans CBS562, gave mean value $S_{S M}=0.921$. This value is in agreement with the minimum acceptable value obtained in previous studies (51). The similarity of the electrophoretic wholecell protein patterns among $C$. albicans samples observed in UPGMA dendrograms showed values among $80 \%$ and $100 \%$ ( 0.8 $\left.\leq S_{S M} \leq 1.0\right)$. These values also are in agreement with the minimal classification value (0.8) proposed by Sneath and Johnson (51). Common and frequent mechanisms involved in the diversity of Candida species could explain this similarity. These include chromosomal rearrangements, chromosomal alteration, and complex and unknown gene regulations $(42,43)$. Moreover tandemly repetitive sequences and telomeric and subtelomeric sequences have been described previously, and it has been postulated that such sequences may be involved in chromosome organization and rearrangements $(12,44)$. Further, these $C$. albicans samples could derive from a unique strain as consequence of the loss of one allele by recombination or a chromosomal rearrangements sensu lato (40).

The UPGMA dendrograms analyses showed several $C$. albicans subtypes and their similarity degrees (80\% to $100 \%$ ). Certain patients may be infected with two or more $C$. albicans subtypes in identical anatomical sites, such as in oral cavity of immunocompromised patients, blood, and tracheal secretion (dendrograms I, III, and VII), or yet, two or more patients can be infected with a same $C$. albicans subtype in identical anatomical sites, such as in bronchial washing, urine, oral cavity, tracheal secretion, vaginal secretion, and healthy saliva (dendrograms II, V, VI, VII, VIII, and IX). However, two or more patients also may be infected with different $C$. albicans subtypes in corresponding sites, such as in oral cavity of immunocompromised patients, blood, oropharyngeal secretion, oral cavity, tracheal secretion, vaginal secretion, and healthy saliva (dendrograms I, III, IV, VI, VII, VIII, and IX). Two or more patients may also be infected with identical or different $C$. albicans subtypes, however, in different anatomical sites as shown in dendrogram $X$ (i.e.1. identical subtypes in vaginal secretion, tracheal secretion, and urine; abdominal secretion and spittle; drainage and oral cavity; catheter and healthy saliva; i.e.2. different subtypes in bronchial washing, oropharyngeal secretion, pulmonary secretion, oral cavity of immunocompromised patients, and blood).

Candida species can be carried as commensal organisms, and it has been showed that at least two-thirds of healthy individuals carry these microorganisms in their natural microflora. In a significant number of cases such individuals harbor this yeasts in at least two anatomical niches, most notably in the vaginal canal and oral cavity (53). Serotyping, electrophoretic karyotyping, and DNA restriction fragment length polymorphism studies have shown that isolates recovered from one or several clinical sites of the same patients are usually identical $(4,7,18,54)$. DNA fingerprinting with the complex probe $\mathrm{Ca} 3$ was used to analyze the relatedness of $C$. albicans collected from individuals with nosocomial bloodstream infections (BSIs) and hospital care workers in the surgical and neonatal intensive care units (ICU). Such research revealed that for the majority of patients, isolates from commensal sites (stool, urine, and others body locations) before and after collection of a BSI isolates were highly similar or identical BSIs. Although has been demonstrate that single, dominant endemic strains are not responsible for nosocomial BSIs in neonatal and surgical ICUs, multiple endemic strains may be responsible for a significant number of cases. These results also suggest that cross-contamination occurs between patients and hospital care workers in the same or different ICUs (31). By similar analyses, clinical samples isolated from patients of different cities showed genetic similarity, despite of the geographic regions $(46,61)$. The genetic dissimilarities among commensal strains of Candida species present in different anatomical locations of the same healthy women were investigated (53). Also the infecting strains of recurrent Candida vaginitis have been reported to be genetically unstable (48), however, a single strain usually predominate in different body site of the patients and in their partners, which it is maintained throughout sequential infections (29). Further, the genetic similarity between $C$. albicans strains 
isolated from women with vulvovaginitis and their male partners $(47,54)$, or those isolated from family members showing same activities also has been reported (33). The isoenzyme and DNA fingerprinting analyses from $C$. albicans samples showed that clinical isolates strictly related were highly similar (39). Recently, multilocus enzyme electrophoresis analysis showed that healthy children may harbor just one or more $C$. albicans genetic subtypes (32), and similarly in immunocompromised patients with predominance of a single strain, which could to result from intraspecies competition (40). Such behave may explain the prevalence of $C$. albicans subtypes highly similar in several anatomical sites. Identical and different $C$. albicans subtypes colonizing intra and inter patients clinically nonimmunocompromised in several anatomical sites (pharynx, bronchia, urine, skin, drainage, and cicatrix) also was reported by electrophoretic enzymatic patterns analysis (4). Similar $C$. albicans subtypes are shown in the oral cavity of HIV-positive individuals in initial and advanced immunosuppression stages, although most patients are infected with a unique strain (38). In other study, identical and different $C$. albicans subtypes were responsible to induce oropharyngeal candidiasis in several HIVpositive patients (35). Finally, no association between clinical site and subtypes $C$. albicans isolated of several anatomical sites (blood, wound, lung, urine, oropharynx, pleural fluid, bile, mouth, groin, and feces) in a same or different bone marrow transplant patients was observed. Thus, in some patients, subtypes may persist over time and strains of the same subtype may colonize multiple anatomic sites (11).

The similarity among $C$. albicans subtypes isolated from several anatomical sites in distinct clinical patients was observed. Nevertheless, complementary studies involving anatomical sites from immunocompetent or immunocompromised patients (before, during and after specifics therapies) and their families or hospital workers must be done in order to establish the sources of $C$. albicans colonization. Finally, differentiation and numerical analysis of Candida species based on SDS-PAGE may provide preliminary criteria for taxonomic and epidemiological studies of such microorganisms.

\section{ACKNOWLEDGMENTS}

This research was supported by FAPESP (Proc. 98/01421-8).

\section{RESUMO}

\section{Eletroforese de proteínas totais e análise numérica de Candida albicans isolada da cavidade oral e outros sítios anatômicos de humanos}

O objetivo da presente pesquisa foi analisar os graus de polimorfismos protéicos entre isolados de $C$. albicans provenientes de diversos sítios anatômicos de quarenta e dois pacientes clínicos, através do emprego da eletroforese em gel de poliacrilamida (SDS-PAGE) e análise numérica, a fim de se identificar subespécies e suas similaridades nos diversos nichos infecciosos. Culturas celulares foram desenvolvidas em meio YEPD, coletadas por centrifugação e lavadas com solução salina gelada. As proteínas celulares totais, foram extraídas por rompimento celular, usando pérolas de vidro e submetidas à técnica de SDS-PAGE. Após a eletroforese, as bandas de proteínas foram coradas com coomassie-blue e analisadas pelo conjunto de programas estatístico NTSYS-pc versão 1,70. Matrizes de similaridade e dendrogramas foram gerados pela aplicação do coeficiente de similaridade simple-matching e do algoritmo UPGMA, respectivamente. Os resultados obtidos revelaram vários subtipos de C. albicans e seus graus de similaridade (80\% a 100\%). Tais dados permitiram demonstrar que, certos pacientes podem estar infectados com dois ou mais subtipos de C. albicans em determinados sítios anatômicos (i.e. apenas na cavidade oral de pacientes imunocomprometidos, sangue ou secreção traqueal), ou ainda, dois ou mais pacientes podem estar infectados em sítios anatômicos idênticos (i.e. apenas em lavagem brônquica, urina, cavidade oral, secreção traqueal, secreção vaginal ou saliva saudável) com um mesmo subtipo de $C$. albicans. No entanto, dois ou mais pacientes também podem apresentar infecções em sítios correspondentes (i.e. apenas na cavidade oral de pacientes imunocomprometidos, sangue, secreção orofaríngea, cavidade oral, secreção traqueal, secreção vaginal e saliva saudável) por diferentes subtipos de C. albicans. Além disso, dois ou mais pacientes também podem estar infectados com subtipos idênticos ou não de $C$. albicans em diferentes sítios anatômicos (i.e.1. idênticos subtipos na secreção vaginal, secreção traqueal e urina; secreção abdominal e escarro; drenagem e cavidade oral; cateter e saliva saudável - i.e.2. diferentes subtipos em lavagem brônquica, secreção orofaríngea, secreção pulmonar, cavidade oral de pacientes imunocomprometidos e sangue). Dados complementares envolvendo amostras de $C$. albicans isoladas de vários sítios anatômicos de pacientes imunocompetentes ou imunocomprometidos (antes, durante e após terapias específicas) e seus familiares ou trabalhadores hospitalares, deverão ser obtidos a fim de se estabelecer as possíveis fontes de colonização por esses microrganismos. De modo geral, os perfis de proteínas totais obtidos por SDS-PAGE associados com análise numérica computadorizada, permitem a obtenção de critérios adicionais para os estudos epidemiológicos e taxonômicos de C. albicans.

Palavras-chave: análise numérica, SDS-PAGE; C. albicans; sítios anatômicos

\section{REFERENCES}

1. Alfenas, A.C. Eletroforese de isoenzimas e proteínas afins; fundamentos e aplicações em plantas e microrganismos. Viçosa, Editora UFV, 1998. p.574. 
2. Ames, G.F.L. Resolution of bacterial proteins by polyacrylamide gel electrophoresis on slabs. J. Biol. Chem., 249: 634-644, 1974.

3. Antonsson, B.; Montessuit, S.; Friedli, L.; Payton, M.A.; Paravicini, G. Protein kinase $\mathrm{C}$ in yeast. Characteristics of the Saccharomyces cerevisiae PKC1 gene product. J. Biol. Chem., 269: 16821-16828, 1994.

4. Arnavielhe, S.; Blancard, A.; Mallié, M.; Gouin, F.; Ottomani, A.; Manelli, J.C.; Bastide, J.M. Suivi mycologique d'infections à Candida albicans dans divers services hospitaliers. Typage molécularie des souches isolées et enquête épidémiologique. Path. Biol., 44: 447451, 1996.

5. Asakura, K.; Iwaguchi, S.; Homma, M.; Sukai, T.; Higashide, K.; Tanaka, K. Electrophoretic karyotypes of clinically isolated yeasts of Candida albicans and C. glabrata. J. Gen. Microbiol., 137: 25312538, 1991.

6. Bradford, M.M. A rapid and sensitive method for the quantitation of microgram quantities of protein utilizing the principle of proteindye binding. Analyt. Biochem., 72: 248-254, 1976.

7. Brawner, D.L.; Anderson, G.L.; Yuen, K.Y. Serotype prevalence of Candida albicans from blood culture isolates. J. Clin. Microbiol., 30: 149-153, 1992.

8. Bruneau, S.; Guinet, R. Rapid identification of medically important yeasts by electrophoretic protein patterns. FEMS Microbiol. Lett., 49: 329-333, 1989.

9. Casanova, M.; Chaffin, D.W.L. Cell wall glycoproteins of Candida albicans as released by different methods. J. Gen. Microbiol., 137: 1045-1051, 1991.

10. Cato, E.P.; Hash, D.E.; Holdman, L.V.; Moore, W.E.C. Electrophoretic study of Clostridium species. J. Clin. Microbiol., 15: 688-702, 1982

11. Caugant, D.A.; Sandven, P. Epidemiological analysis of Candida albicans strains by multilocus enzyme electrophoresis. J. Clin. Microbiol., 31: 215-220, 1993.

12. Chibana, H.; Iwaguchi, S.I.; Homma, M.; Chindamporn, A.; Nakagawa, Y.; Tanaka, K. Diversity of tandemly repetitive sequences due to short periodic repetitions in the chromosomes of Candida albicans. J. Bacteriol., 176: 3851-3858, 1994.

13. Costas, M.; Holmes, B.; Wood, A.C.; On, S.L.W. Numerical analysis of electrophoretic protein patterns of Providencia rettgeri strains from human faeces, urine and other specimens. J. Appl. Bact., 67: 441-452, 1989a.

14. Costas, M.; Sloss, L.L.; Owen, R.J.; Gaston, M.A. Evaluation of numerical analysis of SDS-PAGE of protein patterns for typing Enterobacter cloacae. Epidem. Infect., 103: 265-274, 1989b.

15. Diaz-Guerra, T.M.; Martinez-Suarez, J.V.; Laguna, F.; RodriguesTudela, J.L. Comparison of four molecular typing methods for evaluating genetic diversity among Candida albicans isolates from human immunodeficiency virus-positive patients with oral candidiasis. J. Clin. Microbiol., 35: 856-861, 1997.

16. Eze, J.M.O.; Dumbroff, E.B. A comparison of the Bradford and Lowry methods for the analysis of protein in chlorophyllous tissue. Can. J. Bot., 60: 1046-1049, 1982.

17. Farris, J.S. On the cophenetic correlation coefficient. Systematic Zool., 18: 279-285, 1969a.

18. Fox, B.C.; Mobley, H.L.T.; Wade, J.C. The use of a DNA probe for epidemiological studies of candidiasis in immunocompromised hosts. J. Infec. Dis., 159: 488-494, 1989.

19. Hall, R. Symposium on the use of electrophoresis in the taxonomy of algae and fungi. Electrophoretic protein profiles as criteria in the taxonomy of fungi and algae. Bull Torrey Bot. Club, 100: 253-259, 1973.

20. Hellstein, J.; Vawter-Hugart, H.; Fotos, P.; Schmid, J.; Soll, D.R. Genetic similarity and phenotypic diversity of commensal and pathogenic strains of Candida albicans isolated from the oral cavity. J. Clin. Microbiol., 31: 3190-3199, 1993.
21. Höfling, J.F.; Rosa, E.A.R.; Pereira, C.V.; Boriollo, M.F.G.; Rodrigues, J.A.O. Differentiation and numerical analysis of oral yeasts based on SDS-PAGE profiles. Influence of the culture media on the whole-cell protein extracts. Braz. J. Biol., 61: 507-516, 2001.

22. Holmes, B.; Costas, M.; Sloss, L.L. Numerical analysis of SDS-PAGE protein patterns of Serratia marcescens: a comparison with other typing methods. Epidem. Infect., 105: 107-117, 1990.

23. Izard, D.; Ferragut, C.; Gavini, F.; Kersters, K.; De Ley, J.; Leclerc, G. Klebsiella terrigena, a new species from soil and water. Int. J. Syst. Bacteriol., 31: 116-127, 1981.

24. Kaaren, G.V.; Joly, S. Carriage frequence, intensity of carriage, and strains of oral yeast species vary in the pogression to oral candidiasis in guman immunodeficiency virus-positive individuals. J. Clin. Microbiol., 40: 341-350, 2002.

25. Kersters, K. Numerical methods in the classification of bacteria by protein electrophoresis. In: Goodfellow, M.; Jones, D.; Priesr, F.G. Computer-assisted bacterial systematics. London, Academic Press, 1985. p.337-368.

26. Kersters, K.; De Ley, J. Identification and grouping of bacteria by numerical analysis of their electrophoretic protein patterns. J. Gen. Microbiol., 87: 333-342, 1975.

27. Laemmli, U.K. Cleavage of structural proteins during the assembly of the head of bacteriophage T4. Nature, 227: 680-685, 1970.

28. Lehmann, P.F.; Kemker, B.J.; Hsiao, C.B.; Dev, S. Isoenzyme biotypes of Candida species. J. Clin. Microbiol., 27: 2514-2521, 1989b.

29. Lockhart, S.R.; Reed, B.D.; Pearson, D.L.; Soll, D.R. Most frequent scenario for recurrent candida vaginitis is strain maintenance with "substrain shuffling": demonstration by sequential DNA fingerprinting with probes Ca3, C1 and CARE2. J. Clin. Microbiol., 34: 767-777, 1996.

30. Maiden, M.F.J.; Tanner, A. Identification of oral yeasts by polyacrylamide gel electrophoresis. Oral Microbiol. Immunol., 6: 187-190, 1991.

31. Marco, F.; Lockhart, S.R.; Pfaller, M.A.; Pujol, C.; Rangel-Frausto, M.S.; Wiblin, T.; Blumberg, H.M.; Edwards, J.E.; Jarvis, W.; Siman, L.; Patterson, J.E.; Rinaldi, M.G.; Wenzel, R.P.; The NEMIS study group; Soll, D.R. Elucidating the origins of nosocomial infections with Candida albicans by DNA fingerprinting with the complex probe Ca3. J. Clin. Microbiol., 37: 2817-28-28, 1999.

32. Mata, A.L.; Rosa, R.T.; Rosa, E.A.R.; Golçalves, R.B.; Höfling, J.F. Clonal variability among oral Candida albicans assessed by allozyme electrophoresis analysis. Oral Microbiol. Immunol., 15: 350-354, 2000.

33. Mehta, S.K.; Stevens, D.A.; Mishra, S.K.; Feroze, F.; Pierson, D.L. Distribution of Candida albicans genotypes among family members. Diagn. Microbiol. Infec. Dis., 34: 19-25, 1999.

34. Monod, M.; Porchet, S.; Baudraz-Rosselet, F.; Frenk, E. The identification of pathogenic yeast strains by electrophoretic analysis of their chromosomes. J. Med. Microbiol., 32: 123-129, 1990.

35. Nébavi, F.; Arnavielhe, S.; Le Guennec, R.; Ménan, E.; Kacou, A.; Combe, P.; Aoussi, E.; Mallié, M.; Koné, M.; Bastide, J.M. Oropharyngeal candidiasis in AIDS patients from Abidjan (Ivory Coast): antifungal susceptivilities and multilocus enzyme electrophoresis analysis of Candida albicans isolates. Path. Biol., 46: 307-314, 1998.

36. Odds, F.C. Candida and Candidosis. Baltimore: Leisester Univ. Pr., 1979. p. 352 .

37. Owen, R.J.; Jackman, P.J.H. The similarities between Pseudomonas paucimobilis and allied bacteria derived from analysis of deoxyribonucleic acids and electrophoretic protein patterns. J. Gen. Microbiol., 128: 2945-2954, 1982.

38. Powderly, W.G.; Robinson, K.; Keath, E.J. Molecular typing of Candida albicans isolated from oral lesions of HIV-infected individuals. AIDS, 6: 81-84, 1992.

39. Pujol C.; Joly, S.; Lockhart, S.R.; Noel, S.; Tibayrenc, M.; Soll, D.R. Parity among the randomly amplified polymorphic DNA method, 
multilocus enzyme electrophoresis, and Southern blot hybridization with the moderately repetitive DNA probe $\mathrm{Ca} 3$ for fingerprinting Candida albicans. J. Clin. Microbiol., 35: 2348-2358, 1997.

40. Reynes, J.; Pujol, C.; Moreau, C.; Mallie, M.; Renaud, F.; Janbon, F.; Bastide, J.M. Simultaneous carriage of Candida albicans strains from HIV-infected patients with oral candidiasis: multilocus enzyme electrophoresis analysis. FEMS Microbiol. Lett., 137: 269-273, 1996.

41. Rosa, E.A.R.; Rosa, R.T.; Pereira, C.V.; Boriollo, M.F.G.; Höfling, J.F. Analysis of parity between protein-based electrophoretic methods for the characterization of oral Candida species. Mem. Inst. Oswaldo Cruz, 95: 801-806, 2000.

42. Rustchenko, E.P.; Howard, D.H.; Sherman, F. Chromosomal alterations of Candida albicans are associated with the gain and loss of assimilating functions. J. Bacteriol., 176: 3231-3241, 1994.

43. Rustchenko-Bulgac, E.P.; Sherman, F.; Hicks, J.B. Chromosomal rearrangements associated with morphological mutants provide a means for genetic variation of Candida albicans. J. Bacteriol., 172: 1276-1283, 1990.

44. Sadhu, C.; McEachern, M.J.; Rustchenko-Bulgac, E.P.; Schmid, J.; Soll, D.R.; Hicks, J.B. Telomeric and dispersed repeat sequences in Candida yeasts and their use in strain identification. J. Bacteriol., 173: 842-850, 1991

45. Scherer, S.; Stevens, D.A. Application of DNA typing methods to epidemiology and taxonomy of Candida species. J. Clin. Microbiol., 25: 675-679, 1987.

46. Schmid J.; Herd, S.; Hunter, P.R.; Cannon, R.D.; Yasin, M.S.; Samad, S.; Carr, M.; Parr, D.; Mckinney, W.; Schousboe, M.; Harris, B.; Ikram, R.; Harris, M.; Restrepo, A.; Hoyos, G.; Singh, K.P. Evidence for a general-purpose genotype in Candida albicans, highly prevalent in multiple geographical regions, patient types and types of infection. Microbiology, 145: 2405-2413, 1999.

47. Schmid, J.; Voss, E.; Soll, D.R. Computer-assisted methods for assessing strain relatedness in Candida albicans by fingerprinting with the moderately repetitive sequence Ca3. J. Clin. Microbiol., 29: 12361243, 1990.

48. Schroppel, K.; Rotman, M.; Galask, R.; Mac, K.; Soll, D.R. Evolution and replacement of Candida albicans strains during recurrent vaginitis demonstrated by DNA fingerprinting. J. Clin. Microbiol., 32: 2646-2654, 1994.

49. Shechter, Y. Symposium on the use of electrophoresis in the taxonomy of algae and fungi. IV. Electrophoresis and taxonomy of medically important fungi. Bull Torrey Bot. Club, 100: 277-287, 1973.

50. Shen, H.D.; Choo, K.B.; Tsai, W.C.; Jen, T.M.; Yeh, J.Y.; Han, S.H Differential identification of Candida species and other yeasts by analysis of [35S] methionine-labeled polypeptide profiles. Analyt. Biochem., 175: 548-551, 1988.

51. Sneath, P.H.; Johnson, R. The influence on numerical taxonomic similarities of errors in microbiological tests. J. Gen. Microbiol., 72: 377-392, 1972.

52. Sneath, P.H.A.; Sokal, R.Q. Numerical taxonomy. San Francisco, Freeman, 1973.

53. Soll, D.R.; Galask, R.; Schmid, J.; Hanna, C.; Mac, K.; Morrow, B. Genetic dissimilarity of commensal strains of Candida spp. carried in different anatomical locations of the same healthy women. $J$. Clin. Microbiol., 29: 1702-1710, 1991.

54. Stevens, D.A.; Odds, F.C.; Scherer, S. Application of DNA typing methods to Candida albicans epidemiology and correlations with phenotype. Rev. Infect. Dis., 12: 258-266, 1990.

55. Studier, F.W. Analysis of bacteriophage T7 early RNAs and proteins on slabs gels. J. Molec. Biol., 79: 237-248, 1973.

56. Tanner, A.C.R.; Listgarten, M.A.; Ebersole, J.L.; Strzempko, M.N. Bacteroides forsythus sp. nov., a slow growing, fusiform Bacteroides sp. from the human oral cavity. Int. J. Syst. Bacteriol., 36: 213-221, 1986.

57. Vancanneyt, M.; Lerberge, E.V.; Berny, J.F.; Hennebert, G.L.; Kersters, $\mathrm{K}$. The application of whole-cell protein electrophoresis for the classification and identification of basidiomycetous yeast species. Antonie van Leeuwenhoek., 61: 69-78, 1992.

58. Vancanneyt, M.; Pot, B.; Hennebert, G.; Kersters, K. Differentiation of yeast species based on electrophoretic whole-cell protein patterns. Syst. Appl. Microbiol., 14: 23-32, 1991.

59. Waters, M.G.; Blobel, G. Secretory protein translocation in a yeast cell-free system can occur posttranslationally and requires ATP hydrolysis. J. Cell Biol., 102: 1543-1550, 1986.

60. Woontner, M.; Jaehning, J.A. Accurate initiation by RNA polimerase II in a whole cell extract from Saccharomyces cerevisiae. J. Biol. Chem., 265: 8979-8982, 1990.

61. Xu, J.; Wilgalys, R.; Mitchell, T.G. Lack of genetic differentiation between two geographically diverse samples of Candida albicans isolated from patients infected with human immunodeficiency virus. J. Bacteriol., 181: 1369-1373, 1999. 